\title{
Breeding Low-chill Blueberries and Peaches for Subtropical Areas
}

\author{
Paul M. Lyrene \\ Horticultural Sciences Department, University of Florida, Gainesville, FL 32611
}

Additional index words. Vaccinium corymbosum, Prunus persica, chilling requirement, recurrent selection

\begin{abstract}
Breeding to adapt temperate-zone fruit to subtropical production areas has been a formidable objective because so many different characteristics have to be changed, most of which are controlled by many genes. Recurrent selection is the only breeding method that can accomplish the required wholesale reorganization of the physiology of the plant. The principles of recurrent selection, developed and tested using short-generation organisms like fruit flies, rats, and maize, have been applied to the development of low-chill highbush blueberry ( $V$. corymbosum L.) and peach [Prunus persica (L.) Batsch.] cultivars for northern and central Florida. These principles include using many parents per generation of crosses, minimizing the time between cycles of selection, and selecting simultaneously for all heritable traits that are important in the final product, with traits of highest economic importance and highest heritability being given the highest weight in selecting parents. Many characteristics changed during the breeding of low-latitude peach and highbush blueberry cultivars, including chill requirement, photoperiod response, resistance to various disease and insect pests, fruit chemistry, and growth patterns during a long growing season.
\end{abstract}

The concept of subtropics is ill-defined. The word may be used to refer to certain zones of latitude north or south of the equator or to a collection of climate types in which freezes are infrequent or not very severe. Here I will use the term to refer to areas colder than the tropics but warmer than the temperate zone. Subtropical Mediterranean climates have cool, rainy winters and hot, dry summers - for example, the climate of coastal southern California. Subtropical monsoon climates have hot, rainy summers, and cool, dry winters, as does the climate of Miami, Fla. Fall, winter, and spring in Florida are normally much drier than summer, although, during El Niño winters, the period from December through March can be quite rainy. The spring drought, which lasts from March through early June, is favorable for the production and harvest of peaches and blueberries. After the June rains begin, harvest conditions for perishable fruit become quite unfavorable. Northern Florida normally receives about 10 killing freezes per year, and the expected lowest temperature of any one year is about $-7^{\circ} \mathrm{C}$.

Each plant breeder has a certain environment in which his or her cultivars are supposed to do well. Each growing area presents hardships that the cultivars must endure. The far north has hard winter cold and a short growing season. The tropics have a plethora of diseases and insects. In the subtropics, one major problem is variable winter temperature. One day brings warmth that stimulates plant growth; the next day brings freezing temperatures that kill flowers and new shoots.

There are two ways to breed for subtropical adaptation. One is to start with wild germplasm that is already adapted to the subtropics. Using this adapted germplasm, the breeder works to develop all of the horticultural characteristics needed in a commercial cultivar. The second approach is to start with elite cultivars available from colder areas and breed to adapt them to subtropical conditions.

Many crops were first bred in temperate regions with cold winters. The list includes apples, blueberries, peaches, grapes, cherries, apricots, plums, pears, and many others. For the breeder who wishes to adapt these crops to the subtropics, excellent temperate-zone cultivars are available, and it is not necessary to start the breeding program from wild foundation stock.

\section{Subtropical Adaptation as a Recalcitrant Trait}

Why should subtropical adaptation be considered a recalcitrant trait? An answer can be found in the history of highbush blueberry breeding in Florida. In 1950, Ralph Sharpe decided to breed peaches and highbush blueberries that would thrive in northern Florida (Sharpe and Shoemaker, 1958). He reasoned that if these crops could be grown in northern Florida, where spring comes a month earlier than in eastern North Carolina, harvest could also begin a month earlier than in North Carolina.

Improved peaches and highbush blueberries had already been grown for many years in New Jersey and Michigan. These northern cultivars were reasonably productive as far south as southeastern North Carolina and in the highlands of northern Georgia and South Carolina. If they were taken farther south, the cultivars suffered from lack of chilling. As a result, both flower and vegetative buds broke dormancy late and unevenly in the spring. In severe cases of under-chilling, the flower buds aborted in the spring. In cases of partial chilling, the crop was late-ripening, inconsistent from year to year, reduced in volume, and spread over a long season. The plants also were unthrifty.

At the start, Sharpe believed that the high chilling requirement of the northern cultivars explained why they were not productive in northern Florida. Over the next 30 years of breeding work, however, Sharpe learned that this explanation was a great oversimplification-high chilling requirement was only one of a multitude of factors that made northern cultivars ill-adapted in the warmer parts of the southeastern U.S. Breeding for subtropical adaptation is a long process only because it is necessary to reorganize so many different systems in the plant. Photoperiods differ between temperate and subtropical zones throughout the year. The length of the growing season is doubled, and plants are exposed to a different set of disease and insect pests.

\section{Chilling and Subtropical Adaptations}

Chilling requirement is one of the most conspicuous and mysterious features that must be adjusted in adapting temperate-zone plants to the subtropics. The chilling requirement is a widespread adaptation in woody species of the temperate zone. It helps keep plants dormant during the season of freezes, even when temperatures are warm enough to promote growth. Without the chilling requirement, plants of many species would repeatedly grow and be frozen during the winter; the flowers and fruit would seldom survive until spring.

There is an extensive literature on the chilling requirement, but here I will summarize only the major points: chilling requirement is highly heritable, high-chill parents produce high-chill offspring, high $\times$ low-chill progeny are intermediate, and $\mathrm{F}_{2}$ populations segregate as though the chilling requirement is controlled by many genes.

In blueberries, leaf buds and flower buds on the same stems can have different chilling requirements, but in general, their reactions are closely correlated.

Chilling is perceived by individual branches and buds. Chilling that is received by one branch is not transferred throughout the tree. Frederick Coville (1916) showed this by keeping an unchilled blueberry plant in a warm greenhouse through the winter in Washington, D.C. He made a hole in the side of the greenhouse and let one branch extend out into the cold air of a Washington winter. The following spring, only that branch flowered and leafed normally. The part of the plant that was inside the greenhouse remained dormant late into the spring.

Under certain conditions, low-chill blueber- 
ries and peaches can go through the winter without entering dormancy. By avoiding dormancy, the plant grows vigorously in the spring, even if it has received little or no chilling. Shorter days and lower temperatures cause plants to enter winter dormancy. Low soil fertility also promotes winter dormancy. To avoid winter dormancy, growers need low-chill cultivars, a mild winter, low latitude (probably $<35^{\circ}$ unless supplemental light is provided), and favorable soil fertility and moisture.

In peach, the chilling requirement of a cultivar can be judged by when it flowers in the spring. Low-chill cultivars flower first, high chill cultivars last. This system of rating the chilling requirement of cultivars works well in peaches because peach shows little variation in the amount of heat required to bring about flowering after chilling is satisfied. Hence, bloom date in peach is controlled primarily by chilling requirement. In blueberry, however, cultivars differ greatly in how many heat units are required to bring flowering after chilling is satisfied. This makes it harder with blueberries to determine, and to specify with a number, the chilling requirement of a cultivar.

Chemical treatments, such as spraying the dormant plants with an aqueous solution of hydrogen cyanamide, can reduce the chilling requirement of many deciduous species.

How can the chilling that has been received at a given location in a given winter be quantified or determined? There are several methods to choose from, such as counting the number of hours when the temperature is below $7{ }^{\circ} \mathrm{C}$ (Weinberger, 1950), using the Richardson model (1974), which assigns specific chilling effects to each temperature, and simply determining the mean temperature for the 90 days of winter. Buds seem not to record chill units if they have not yet become dormant, and chilling accumulation seems to end in the spring long before the last cold is past. This makes it hard to know exactly when to start and end the chill accumulation measurements. As a practical matter, in northern Florida, the period 1 Nov. to $10 \mathrm{Feb}$. seems a reasonable chilling window to use for plants that are not too young or excessively vigorous.

What occurs inside the plant during chill accumulation is poorly understood. The chilling process seems analogous to what happens during the cold-stratification of seeds. Symptoms of lack of chilling in peach and blueberry include delayed flowering and leafing, unsynchronized flowering and leafing from different buds on the same branch, and flower bud abortion. Flower bud abortion is called bud drop in peach and almond. Apricots in northern Florida abscise almost all of their flowers every year, even though the trees grow fairly well. This abscission is believed to be due to variable temperatures during the winter (Weinberger, 1967).

Highbush blueberry cultivars vary in their tendency to abort under-chilled flower buds. Some, like 'Jubilee' and 'Magnolia', normally abort all flower buds that have not opened by 10 Mar. in northern Florida, which is most buds in most years. Other cultivars, such as 'Legacy' and late-ripening rabbiteye (Vaccinium ashei
Reade) cultivars such as 'Powderblue' and 'Brightwell,' can flower as late as 10 Apr. with little flower bud abortion.

\section{Breeding}

\section{Recurrent selection}

There is only one method of plant breeding that can simultaneously change scores of traits, each controlled by hundreds of genes. The method is called recurrent selection, and, in brief, it works as follows. The breeder starts with a large and diverse group of plants to use as parents. In breeding low-chill deciduous cultivars, the beginning pool of parents will include a few dozen of the best high-chill cultivars, which have excellent horticultural characteristics, and a few dozen low-chill selections, which have excellent local adaptation and as much horticultural merit as can be found, which may be little or none. A large number of crosses are made using these foundation parents in various combinations. The parent plants are highly heterozygous, so even in the first crosses, the seedling populations segregate for a multitude of characteristics, every seedling being different from every other.

In doing recurrent selection with southern highbush blueberries in Florida, we use 200 different genotypes as parents each generation. These are crossed, one on one, to produce 100 different crosses. We grow 100 seedlings from each cross, for a total of 10,000 seedlings per generation. From these 10,000 seedlings, we select the best 200 to use as parents in the next generation of crosses. This process goes on and on, generation after generation-10,000 seedlings give 200 parents, which give 10,000 seedlings which give 200 parents. Advanced selections in the Florida blueberry breeding program have been through about 7 generations of selection since 1975, and about 12 generations of selection since the first high-chill $\mathrm{x}$ low-chill crosses were made in 1950.

Here are some features of a well-designed recurrent selection program. In choosing parents, all traits that are important in cultivars must be taken into account, each trait being weighted according to its heritability and its relative importance to the growers who will use the cultivars. The number of traits the breeder will consider in choosing parents is likely to be 50 to 100 . A plant that is spectacular for one trait but below average for most of 99 other traits probably has little value, either as a cultivar or as a parent.

In recurrent selection, progress is additive from one generation to the next. If one breeder finishes 10 generations of selection in a lifetime, and another only five, the 10-generation breeder is likely to make more progress . One advantage of breeding tree fruit in warm areas is that the growing season is very long, and the breeder can grow seedlings to fruiting and evaluation age faster than breeders at higher latitudes. The long growing season lets the breeder complete more cycles of selection during a lifetime of breeding.

The enemies of recurrent selection include inbreeding depression and the depletion of genetic variability. The use of 200 parents per generation of breeding is intended to avoid inbreeding depression and the loss of variability. Other enemies of recurrent selection include traits of low heritability - traits in which plants that look unusually good have little or no tendency to pass on their superiority to their progeny. It is the art and skill of the breeder to notice which traits are responding to selection and which are not.

\section{Breeding problems}

Blueberry. In breeding low-chill blueberries, numerous problematic clones are encountered that flower long before they leaf in the spring. The early flowers produce fruit, but there is no leaf canopy to support the developing berries. In some cases, $60 \mathrm{~d}$ after flowering, berries are starting to ripen but the plant still has only a few sparse leaves. This is a disastrous situation-it is bad for plant health and it is bad for berry quality. In recent years we have selected strongly for plants that leaf profusely at the time they begin to flower in the spring.

In subtropical areas where leaf diseases can be controlled, it is possible to develop cultivars that ripen the spring crop using leaves produced the previous year. This avoids the problem of having to get strong new leafing in the spring. One place where this has been done successfully is in subtropical eastern Australia near latitude 30 . In this area, some low-chill southern highbush blueberry cultivars are evergreen through the winter. The plants flower in midwinter, and, because killing freezes are rare and winter temperatures are warm enough to promote growth, the berries ripen in early spring. Harvest is finished before significant new leafing occurs. Soon after harvest is complete, the plants are severely pruned by hedging, and the new leaves that come after pruning persist through the summer and the subsequent winter. These mature leaves support the berry crop as it develops in late winter and early spring. This evergreen system allows the harvest of berries about one month earlier than from low-chill deciduous cultivars on the same farm.

The long growing season in subtropical areas requires major adaptive changes in the plant. In Michigan and British Columbia, the end of blueberry harvest nearly coincides with the end of the growing season. By the time the last berries are picked, the plant has finished growing for the year, and flower buds for next year's crop are already present. In a few weeks, the plants will enter winter dormancy. In northern Florida, when the last highbush blueberries are harvested on 15 May, 6 months of growing season remain before frost. To produce a good crop the next year, the plants need to continue growing through the summer. For a full crop, leaves that formed on the first flushes of February and March must be kept healthy through the hot months of summer and fall.

Keeping blueberry leaves healthy until frost in Florida requires that the plants have good resistance to various fungal pathogens, including blueberry rust [Pucciniastrum vaccinii (G. Wint.) Jorst], septoria leaf spot (Septoria albopunctata Cooke), gloeosporium leaf spot 
(Gloeosporium minus Shear), powdery mildew [Microsphaera vaccinii (Schwein.) Cooke \& Peck], phyllosticta leaf spot (Phyllosticta vaccinii Earle and P. elongata G.J Weidemann), and several other fungi. Peach leaves may abscise prematurely during the fall due to peach leaf rust [Tranzschelia discolor (Fuckel) Tranz. and Litv.]. This causes the plants to produce a new flush of leaves late in the fall, along with a flush of flowers which will not set fruit that survives until spring. These wasted flowers can reduce yield.

In blueberry, flower buds are induced on current-season growth by the cooler nights and shorter days of fall. Because fall is so warm in Florida, some blueberry clones do not make enough flower buds to produce a full crop. For the warmer parts of Florida, cultivars are required that produce numerous flower buds despite warm fall temperatures. If these cultivars are planted in colder areas, they may produce too many flower buds, resulting in a bush that overfruits in the spring. Over-fruiting reduces berry size, delays ripening, interferes with proper leafing, and may jeopardize the life of the bush. Winter pruning can remove excess flower buds and prevent over-fruiting, but some cultivars make so many flower buds that there is not much plant left if the excess flower buds are removed. Regarding flower bud numbers, growers must match the cultivar to the growing zone to get a favorable balance between leafing and flowering in the spring.

In both peach and rabbiteye blueberry, a long, rainy growing season can result in excessive vegetative growth during the summer. Unless soil moisture and fertility are carefully regulated, plants may make 2 m of new growth during the summer, and the following spring, the fruit will be high in the plant at the tips of long, vigorous shoots.

Late summer and fall reveal another problem in the adaptation of temperate-zone cultivars to the subtropics. Whereas native trees and shrubs in northern Florida exploit the long growing season by continuing to grow late into the fall, high-chill blueberries stop growing in northern Florida at about the same time they would in New Jersey, 6 weeks earlier than adapted low-chill cultivars. If low-chill and high-chill blueberry cultivars are potted, placed in a greenhouse in northern Florida in August, fertilized to promote growth, provided with ambient photoperiod and temperatures maintained above freezing through the winter, the low-chill cultivars will grow continuously through the fall and winter, but the high-chill cultivars will go dormant in early October, and no amount of fertilizer or water will keep them growing. This indicates a difference in the way southern highbush and northern highbush blueberry growth responds to photoperiod.

Fruit flavor changes with temperature. Grapefruit are not grown commercially in southern California because cool winters make the fruit too high in acids. By contrast, warm winter nights in southern Florida and southern Texas produce excellent grapefruit. Warm temperatures also reduce fruit acidity in pineapple. In Florida, we developed some rabbiteye blueberry (Vaccinium ashei) clones that ripen a month earlier than the standard rabbiteyes grown in Florida, but the fruit was unpleasantly high in acid if it ripened before mid-May, when the nights were still cool. The heat of June and July was required to give the berries a good flavor. By contrast, southern highbush blueberries that ripen in April and May in Florida can have excellent sugar-toacid ratios.

Northern highbush blueberries that ripen in hot weather can be too low in acid, and this can make them taste bland. Many southern highbush cultivars are able to maintain good flavor in hot weather. This ability may come from their heat-resistant ancestor, Vaccinium darrowi Camp, whose berries mature in the heat of the Florida summer.

Peach. In peach, even plants that flower profusely and have healthy-looking flowers, often do not set fruit if night temperatures are high during flowering. Daily minimum temperatures between flowering and shuck split must average below $14{ }^{\circ} \mathrm{C}$ to get good fruit set on most peach cultivars. Cultivars vary in tolerance to this problem; good fruit set after warm flowering periods is an important trait for selection in peach.

In peach, the shape of the fruit can change for the worse if the temperature is too high during early stages of fruit development. When grown too far south in Florida, some peach cultivars have a pointed tip and a pronounced suture bulge, even though the same fruit is round if grown in Georgia. Again, this problem is amenable to breeding.

\section{Incentives, Problems, and Rewards,}

With all these problems of adaptation, why are peaches and blueberries grown in places like Florida? There are two reasons: to satisfy local markets and to produce early-season fruit for packing and shipping before high-chill zones begin to harvest. The only cultivars that interest Florida growers are those that ripen very early. Growers want to be finished picking before the
Carolinas begin harvest, and certainly before the summer rains begin in Florida.

The need for early harvest puts severe demands on the plant that are not directly related to subtropical adaptation but are directly related to profitable production in the subtropics. If blueberries flower $15 \mathrm{Feb}$. and ripen $15 \mathrm{Apr}$., the plants have only $60 \mathrm{~d}$ to grow new leaves and fill the berries with sugars, pigments, and acids. This stresses the bush and reduces yields compared to long-season cultivars. After harvest is complete, 6 months of warm to hot growing season remains. What are the plants doing during these 6 months? Neither the breeders, nor the growers, nor the plants can sit idle for 6 months until frost. The plants must be kept growing and the foliage must be kept healthy until conditions in the fall are right to induce flower buds for next year's crop.

\section{Summary and Conclusions}

Low-chill cultivars of temperate-zone fruit, including blueberry and peach, have been bred at the University of Florida and at many other fruit breeding stations around the world. In many cases, these breeding programs began with crosses between high-quality cultivars from colder areas and related wild (or less-horticulturally developed) taxa that were well-adapted at lower latitudes. These crosses were followed by several to many generations of recurrent selection to combine local adaptation with good cultivar characteristics. The development of low-chill cultivars with good shipping and storage qualities has resulted in year-round availability of many temperate-zone fruit that were once available only for a few months during the summer in each hemisphere.

\section{Literature Cited}

Coville, F.V. 1916. The wild blueberry tamed. Natl. Geo. Mag. 29(June):535-546.

Richardson, E.A., S.D. Seeley, and D.R. Walker. 1974. A model for estimating the completion of rest for 'Redhaven' and 'Elberta' peach trees. HortScience 9:331-332.

Sharpe, R.H. and J.S. Shoemaker. 1958. Development of temperate-climate fruits for Florida. Proc. Fla. State Hort. Soc. 71:294-300.

Sherman, W.B. and T. G. Beckman. 2003. Climatic adaptation in fruit crops. Acta Hort. 622:411-428.

Weinberger, J.H. 1950. Chilling requirement of peach varieties. Proc. Amer. Soc. Hort. Sci. $55: 122-128$.

Weinberger, J.H. 1967. Studies on flower bud drop in peaches. Proc. Amer. Soc. Hort. Sci. 91:78-83. 